4 Woodhouse NJY, Reiner M, Bordier PH, Malu DN, Fisher M, Foster GV, et al. Human calcitoni in the treatment of Paget's bone disease. Lancet 1971;i:1139-43.

5 Smith R, Russell RGG, Bishop MC, Woods CG, Bishop M. Paget's disease of bone. Experience with a diphosphonate (disodium etidronate) in treatment. Qf Med 1972;42:235-56.

6 Douglas DL, Duckworth T, Kanis JA, Jefferson AA, Martin TJ, Russell RGG. Spinal cord dysfunction in Paget's disease of bone. Has medical treatment a vascular basis? I Bone foint Sur 1981;63B:495-503.

7 Bickerstaff DR, Douglas DL, Burke PH, O'Doherty DP, Kanis JA. Improvement in deformity of the face in Paget's disease treated with diphosphonates. 7 Bone foint Surg 1990;72B:132-6.

8 Cantrill JA, Anderson DC. Treatment of Paget's disease of bone. Clin Endocrinology 1990:32:507-18.
9 Harinck HJJ, Bijvoet OLM, Vellenga JLR, Blanksma HJ, Frijlink WB. Relation between signs and symptoms in Paget's disease of bone. Qf Med 1986;58:133-5

10 Kahn AJ. The viral aetiology of Paget's disease of bone: a new perspective. Calcif Tissue Imt 1990;47:127-9.

11 O'Driscoll JB, Anderson DC. Past pets and Paget's disease. Lancet 1985;ii:919-21.

12 Gordon MT, Anderson DC, Sharpe PT. Canine distemper virus localised in bone cells of patients with Paget's disease. Bone 1991;12:195-201.

13 Selby P, ed. Proceedings of the first international symposium on Paget's disease of bone. Manchester, August 1992. Seminars in arthritis and rheumatism (in press).

14 Kaplan FS. Paget's disease of bone: exploring the questions. Calcif Tissue Int 1992;51:1-3.

\title{
Opting in or out of organ donation
}

\section{The donor card is not dead, but it could benefit from some intensive care}

Since the beginnings of transplantation the subject of donors and organ donation has aroused intense debate. Discussion has been sharpened by a list in Britain of more than 4000 people awaiting kidney transplants and an annual kidney transplant rate of less than half that. There is a much smaller waiting list for heart or lung transplants, which underestimates the need because up to a quarter of those awaiting thoracic organs die before transplantation.

The best method of obtaining consent for organ donation remains controversial. Britain uses an opt in system with the donor card and relatives' consent. Believing that this system is outmoded and has failed to meet the demand for organs, some people advocate changing to an opt out system, as currently practised in Austria, Belgium, and France. In these countries it is assumed that people want to donate their organs unless they have registered a prior objection to donation. Within this opt out framework the wishes of relatives of the deceased are taken into account to varying degrees.

At a recent symposium organised by the Kidney Research Unit Foundation of Wales, Professor Paul Michielsen of Leuven and Professor Raimund Margreiter of Innsbruck described how opting out worked in Belgium and Austria and advocated that Britain should adopt this system, which has a high level of acceptance in the countries that practise it. According to recent figures from Euro Transplant, Austria has achieved 53 and Belgium 40 donor kidneys per million population using opt out (compared with 30 kidneys per million population in Britain).

Last year, however, the Northern region in England had a donor rate of 53 per million, which was the highest ever achieved in Britain and equalled that in Austria, the most successful country practising opt out. The fact that a high donor rate is possible using opt in suggests that there is no inherent defect in the system, only shortcomings in how it is practised. If the donor rate in the Northern region was equalled in the rest of Britain another 1000 kidneys would be available each year for transplantation.

Recent British surveys of public attitudes towards legislation on opting out have shown gradually increasing support: this year's survey by the British Kidney Patient Association found $61 \%$ of the population in favour. ${ }^{1}$ This result differs from that found by the Department of Health-that just under half the population favoured opting out. ${ }^{2}$ Of the $54 \%$ opposed to it, more than half were "very much opposed." A poll of transplant coordinators in Britain, conducted by the United Kingdom Transplant Coordinators Association earlier this year, found that only five were in favour of opting out, with 34 opposed, many of whom were "very opposed." (A Crombie, personal communication). Many members of the Intensive Care Society, who care for most donors, strongly oppose opting out. A poll of transplant doctors who are members of the British Transplantation Society found that $40 \%$ have a clear preference for opting out, $31 \%$ have a clear preference for opting in, and $29 \%$ would work with either system (JD Briggs, personal communication) $\overrightarrow{0}$

These findings suggest only muted enthusiasm amongtransplanters themselves for opting out, and no great mandate exists among the members of the relevant organisation too press for change. Nor is there a considerable majority in. favour of opting out within the general public. The key peopleo to make any system of organ donation work-that is, thes transplant coordinators and intensive care specialists-areo mostly strongly opposed to opt out, which would therefore make it totally unworkable.

How then can opt in be made to work better and reduce the shortfall between supply and demand for lifesaving organs? We need to eliminate the $6 \%$ of families of potential donors who are never asked for consent ${ }^{3}$ and to reduce the $30 \%$ refusal rate by families who are asked about organ donation. $\stackrel{\mathbb{3}}{3}$ We need to look at the possibility of retrieving kidneys fromp victims of road accidents who sustain cardiac arrest after $\overrightarrow{-}$ arrival in hospital. The kidneys of these patients can be coolede by whole body perfusion after cardiac death while consent for organ donation is requested. We need to pursue the possibility of elective ventilation in suitable patients for the purposes only of organ donation.

Above all, we should seek to record within the hospital case notes the patient's wishes regarding organ donation. There is a huge popular mandate for this, with a recent survey showing $86 \%$ of the general public in favour. Fears that requests for such information would cause mass panic among the British public therefore seem unfounded.

For opt in to work, an individual's wishes regarding organ donation need to be known before death and should be readilyo accessible to the medical staff. As all suitable donors die in hospital where better can this information be recorded than iñ the hospital case notes? Most people attend hospital with minor ailments at some time before their final admission? Would it not therefore be better to record in the notes that willingness to donate organs along with other persona? details? This would be more effective than recording patients $=$ wishes in regional or national computerised registers, which 5 so far have a dismal track record. In these ways opting in canw be made efficient and organ donation rates can be substan tially improved.

Now does not seem the time to change the law to opting out for organ donation. The kidney donor card is not dead but may require intensive care to restore it to more robus $\overline{0}$ health.

Consultant Surgeon,

R M R TAYLOR

Royal Victoria Infirmary,

Newcastle Upon Tyne NE1 4LP

1 Social Surveys (Gallup Poll). Attitudes towards kidney doning. London: Gallup, 1992 1 Social Surveys (Gallup Poll). Attitudes towards kidney doning. London: Gallup, 1992.
2 Department of Health. Organ donation: quantitative omnibus research. London: DoH, 1992:
(RS3051.)

3 Taylor RMR, Salaman JR. Obligation to ask for organs. Lancet 1988;i:985-7

4 Gore S, Taylor RMR, Wallwork J. Availability of transplantable organs from brain stem dead donors in intensive care units. $B M \mathcal{F}^{1} 1991 ; 302: 149-53$. 